\title{
Numerical Modeling and Simulation of CIGS-Based Solar Cells with ZnS Buffer Layer
}

\author{
Adama Syllaㅁ, Siaka Touré ${ }^{1}$, Jean-Pierre Vilcot ${ }^{2}$ \\ ${ }^{1}$ Laboratoire d'Energie Solaire, Université Félix Houphouët Boigny, Abidjan, Cote d'Ivoire \\ ${ }^{2}$ Institut d'Electronique, de Microélectronique et de Nanotechnologie (IEMN), UMR, CNRS, 8520. Laboratoire Central, \\ Villeneuve d'Ascq Cedex, Lille, France \\ Email: sylla_adama1959@yahoo.fr
}

How to cite this paper: Sylla, A., Touré, S. and Vilcot, J.-P. (2017) Numerical Modeling and Simulation of CIGS-Based Solar Cells with ZnS Buffer Layer. Open Journal of Modelling and Simulation, 5, 218-231. https://doi.org/10.4236/ojmsi.2017.54016

Received: July 19, 2017

Accepted: October 13, 2017

Published: October 16, 2017

Copyright $\odot 2017$ by authors and Scientific Research Publishing Inc. This work is licensed under the Creative Commons Attribution International License (CC BY 4.0). http://creativecommons.org/licenses/by/4.0/

\begin{abstract}
Usually a buffer layer of cadmium sulphide is used in high efficiency solar cells based on $\mathrm{Cu}(\mathrm{In}, \mathrm{Ga}) \mathrm{Se}_{2}$ (CIGS). Because of cadmium toxicity, many investigations have been conducted to use Cd-free buffer layers. Our work focuses on this type of CIGS-based solar cells where CdS is replaced by a $\mathrm{ZnS}$ buffer layer. In this contribution, AFORS-HET software is used to simulate $\mathrm{n}-\mathrm{ZnO}$ : $\mathrm{Al} / \mathrm{i}-\mathrm{ZnO} / \mathrm{n}-\mathrm{ZnS} / \mathrm{p}$-CIGS/Mo polycrystalline thin-film solar cell where the key parts are p-CIGS absorber layer and n-ZnS buffer layer. The characteristics of these key parts: thickness and Ga-content of the absorber layer, thickness of the buffer layer and doping concentrations of absorber and buffer layers have been investigated to optimize the conversion efficiency. We find a maximum conversion efficiency of $26 \%$ with a short-circuit current of $36.9 \mathrm{~mA} / \mathrm{cm}^{2}$, an open circuit voltage of $824 \mathrm{mV}$, and a fill factor of $85.5 \%$.
\end{abstract}

\section{Keywords}

$\mathrm{Cu}\left(\mathrm{In}_{1-\mathrm{x}} \mathrm{Ga}_{\mathrm{x}}\right) \mathrm{Se}_{2}$, Thin-Film Solar Cell, Numerical Modeling, AFORS-HET Simulation, Optimization

\section{Introduction}

$\mathrm{Cu}(\mathrm{In}, \mathrm{Ga}) \mathrm{Se}_{2}$ is one of the most promising semiconductor materials for photovoltaic conversion based on polycrystalline thin-films. It is a semiconductor of great attraction in recent years as thin-film solar cell absorber material. This is due to its very high optical absorption coefficient and also, the band gap of $\mathrm{CuIn}_{1-\mathrm{x}} \mathrm{Ga}_{\mathrm{x}} \mathrm{Se}_{2}$ can be varied continuously between $1.04 \mathrm{eV}$ and $1.68 \mathrm{eV}$ by changing the gallium content $\mathrm{x}$ [1] [2]. The band gap Eg in eV depends on $\mathrm{x}$ by the approximate relation 


$$
1.04(1-x)+1.65 x-0.21(1-x)
$$

Thus, the CIGS band gap can be tuned to better match the visible incident sunlight spectrum. Recently, the highest efficiency obtained was about $22.6 \%$ in laboratory cells [3]. In addition, the commercialized CIGS-based solar cells have achieved high efficiency compared to crystalline silicon solar cells whose efficiency is around $25 \%$ while they further allow a significant reduction in the cost of solar electricity per watt. However, many physical properties of CIGS alloys are not yet clarified. At present, no definitive measurement has been established about the structural, optical and electronic properties of the CIGS absorber. Various available data about materials properties are changed from one laboratory to another depending on the growth processes and characterization techniques used. The result is that input parameters may vary within wide ranges. This imposes a limitation on the accuracy of our simulated results, mainly the nature of defects and their energy levels in the bulk of the CIGS absorber layer and at the buffer-absorber interface. This problem is still a topic of discussion [4] [5]. Furthermore, due to improvement of CIGS-based solar cells technology, different buffer layers without toxic cadmium have been studied [6] [7]. At present, we are witnessing to the use of $\mathrm{Zn}$-based materials to replace the CdS buffer layer. Several candidates were reviewed including $\mathrm{ZnS}, \mathrm{ZnO}, \mathrm{ZnSe}$ and the ternary compound $\mathrm{ZnO}_{1-\mathrm{x}} \mathrm{S}_{\mathrm{x}}$ which is the most promising material with variable band gap from 3.6 to $3.2 \mathrm{eV}$ [8]. Also, in CIGS-based solar cell the role of the $\mathrm{i}-\mathrm{ZnO}$ layer is still a topic of discussion. It would be used to homogenize the surface distribution of the current density for the cells using a CdS buffer layer (avoid short circuits or preferential paths for the current) and would reduce any leakage currents at the junction.

In this paper, we examine how the thin-film CIGS solar cells performances are modified when replacing the conventional toxic CdS by $\mathrm{ZnS}$ buffer layers. We investigate successively the effects of the thickness and Ga-content of the absorber layer, the thickness of the buffer layer and doping concentrations of absorber and buffer layers. For this purpose, we start from the optimal values of the above parameters in CIGS solar cells with CdS buffer layers, as summarized in Table 1. The values of optical and electrical properties of the materials, used as inputs, have been collected from the literature. We then turn to CIGS solar cells with a $\mathrm{ZnS}$ buffer layer and calculate their main electrical characteristics: short circuit current, open circuit voltage, fill factor and total conversion efficiency, when varying successively the above mentioned parameters. This computation procedure allows us to predict not only the optimal values of the investigated parameters when replacing CdS by ZnS buffer layer, but also to get insight into the sensitivities of the electrical characteristics of the solar cells with respect to variations of each single parameter. The solar cell model is described in Section 2. Section 3 is devoted to the numerical simulation procedure. Optimized results are reported in Section 4 where sensitivities of the solar cell performances with respect to various parameters are discussed. Final conclusions are given in Section 5. 
Table 1. Input parameters used for the solar cell simulation. (a) and (d) denote shallow acceptor and donor while (A)and (D) denote deep acceptor and donor.

\begin{tabular}{|c|c|c|c|c|c|}
\hline \multicolumn{6}{|c|}{ Layers properties } \\
\hline & CIGSe & ODC & $\mathrm{ZnS}$ & $\mathrm{i}-\mathrm{ZnO}$ & $\mathrm{ZnO}: \mathrm{Al}$ \\
\hline Thickness $(\mu \mathrm{m})$ & 3 & $\begin{array}{c}0.015 \\
{[7][10]}\end{array}$ & 0.02 & 0.02 & 0.03 \\
\hline Band gap $E_{g}(\mathrm{eV})$ & 1.19 & 1.34 & 3.6 & 3.2 & 3.2 \\
\hline $\begin{array}{l}\text { Electron affinity } \\
\qquad \chi(\mathrm{eV})\end{array}$ & $\begin{array}{c}4.5 \\
{[10]}\end{array}$ & $\begin{array}{c}4.5 \\
{[10]}\end{array}$ & 4.15 & $\begin{array}{c}4.5 \\
{[10]}\end{array}$ & $\begin{array}{c}4.5 \\
{[10]}\end{array}$ \\
\hline $\begin{array}{l}\text { Dielectric } \\
\text { constant } \varepsilon_{r}\end{array}$ & $\begin{array}{c}13.6 \\
{[7][10]}\end{array}$ & $\begin{array}{c}13.6 \\
{[7][10]}\end{array}$ & 9 & $\begin{array}{c}9 \\
{[7][10]}\end{array}$ & $\begin{array}{c}9 \\
{[7][10]}\end{array}$ \\
\hline $\begin{array}{l}N_{C}\left(\mathrm{~cm}^{-3}\right) / \\
N_{V}\left(\mathrm{~cm}^{-3}\right)\end{array}$ & $\begin{array}{c}6.8 \times 10^{17} / \\
1.5 \times 10^{19} \\
{[7][10]}\end{array}$ & $\begin{array}{c}6.8 \times 10^{17} / \\
1.5 \times 10^{19} \\
{[7][10]}\end{array}$ & $\begin{array}{l}2.2 \times 10^{18} / \\
1.8 \times 10^{19}\end{array}$ & $\begin{array}{c}3 \times 10^{18} / \\
1.7 \times 10^{19} \\
{[7][10]}\end{array}$ & $\begin{array}{c}3 \times 10^{18} / \\
1.7 \times 10^{19} \\
{[7][10]}\end{array}$ \\
\hline$S_{t h}^{p}, \quad S_{t h}^{n} \quad(\mathrm{~cm} / \mathrm{s})$ & \multicolumn{5}{|c|}{$10^{7}$} \\
\hline $\begin{array}{l}\mu_{n}\left(\mathrm{~cm}^{2} / \mathrm{Vs}\right) / \\
\mu_{p}\left(\mathrm{~cm}^{2} / \mathrm{Vs}\right)\end{array}$ & $\begin{array}{l}100 / 50 \\
{[7][10]}\end{array}$ & $\begin{array}{l}10 / 1.25 \\
{[7][10]}\end{array}$ & $100 / 25$ & $\begin{array}{c}100 / 31 \\
{[7]}\end{array}$ & $\begin{array}{l}100 / 31 \\
{[7][10]}\end{array}$ \\
\hline $\begin{array}{l}\text { Doping level } \\
\quad\left(\mathrm{cm}^{-3}\right)\end{array}$ & $2.10^{17}(\mathrm{a})$ & $2.10^{17}$ (a) & $10^{18}(\mathrm{~d})$ & $10^{18}(\mathrm{~d})$ & $10^{20}(\mathrm{~d})$ \\
\hline \multicolumn{6}{|c|}{ Bulk Gaussian defect states } \\
\hline $\mathrm{Nt}\left(\mathrm{cm}^{-3}\right)$ & $\begin{array}{c}10^{14}(\mathrm{D}) \\
{[7][9][10]}\end{array}$ & $\begin{array}{c}10^{14}(\mathrm{D}) \\
{[7][9][10]}\end{array}$ & $10^{17}(\mathrm{~A})$ & $10^{17}(\mathrm{~A})$ & $10^{17}(\mathrm{~A})$ \\
\hline$E_{G D}, E_{G A}(\mathrm{eV})$ & \multicolumn{5}{|c|}{ Mid-gap } \\
\hline$W_{G D}, W_{D A}(\mathrm{eV})$ & \multicolumn{5}{|c|}{0.01} \\
\hline $\begin{array}{c}\sigma_{n}\left(\mathrm{~cm}^{2}\right) / \\
\sigma_{p}\left(\mathrm{~cm}^{2}\right)\end{array}$ & $\begin{array}{c}10^{-13} / \\
10^{-15} \\
{[7][10]}\end{array}$ & $\begin{array}{c}10^{-13} / \\
10^{-15} \\
{[7][10]}\end{array}$ & $\begin{array}{c}10^{-15} / \\
5 \times 10^{-13} \\
{[7][10]}\end{array}$ & $\begin{array}{c}10^{-15} / \\
5 \times 10^{-13} \\
{[7][10]}\end{array}$ & $\begin{array}{c}10^{-15} / \\
5 \times 10^{-13} \\
{[7][10]}\end{array}$ \\
\hline \multicolumn{6}{|c|}{ Interface Gaussian defect states } \\
\hline & CIGSe/ODC & OD & $\mathrm{C}(\mathrm{CIGSe}) / \mathrm{ZnS}$ & & $\mathrm{ZnS} / \mathrm{i}-\mathrm{ZnO}$ \\
\hline$\Delta E_{C}(\mathrm{eV})$ & 0 & & $0.35(0.35)$ & & -0.35 \\
\hline$\Delta E_{V}(\mathrm{eV})$ & -0.15 & & $-1.91(-2.06)$ & & 0.05 \\
\hline$N t\left(\mathrm{~cm}^{-2}\right)$ & $10^{10}(\mathrm{D})$ & & $3 \times 10^{18}(\mathrm{D})$ & & - \\
\hline$E_{G D} / E_{G A}(\mathrm{eV})$ & & & Mid-gap & & \\
\hline$W_{G D} / W_{D A}(\mathrm{eV})$ & & & 0.01 & & \\
\hline $\begin{array}{c}\sigma_{n}\left(\mathrm{~cm}^{2}\right) / \\
\sigma_{p}\left(\mathrm{~cm}^{2}\right)\end{array}$ & $\begin{array}{l}10^{-13} \\
10^{-15}\end{array}$ & & $\begin{array}{l}10^{-13} \\
10^{-15}\end{array}$ & & $-[7][10]$ \\
\hline
\end{tabular}

\section{Description of the Solar Cell Model}

In the present study the CIGS cell structure is consisted of seven stacked layers including the top and back contacts. The CIGS-based solar cell schematic energy-band diagram is illustrated in Figure 1. Based on previous work [9] [10] [11] [12] the contacts are assumed ohmic with surface recombination velocities $S_{n}=S_{p}=10^{7} \mathrm{~cm} / \mathrm{s}$. According to authors, a layer called ordered defect compound (ODC) or surface defect layer (SDL) is present between the absorber and 


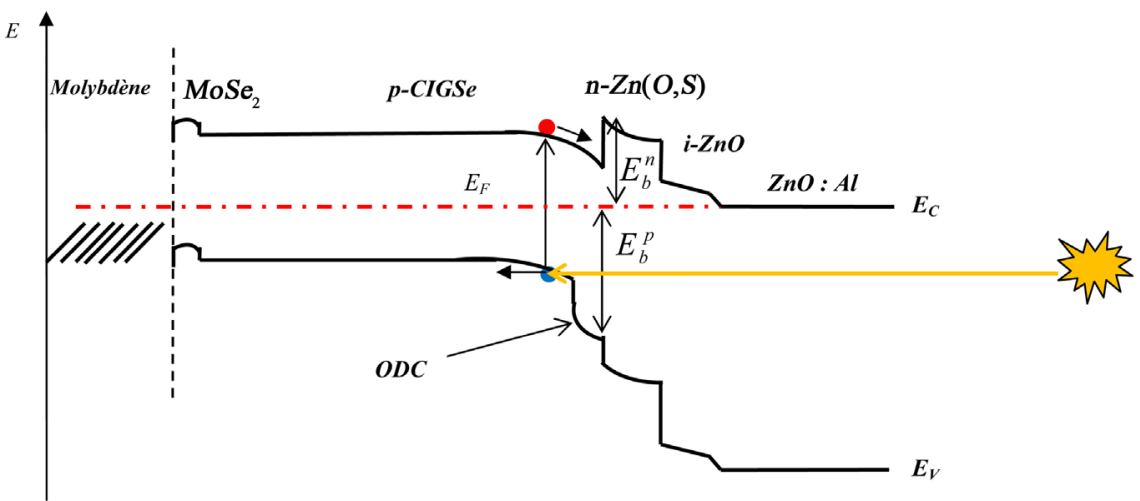

Figure 1. Band diagram of CIGS-based solar cells.

buffer layers. This layer is considered to improve the CIGS cells performance because it increases the absorber band gap at the buffer-absorber interface by lowering the valence band maximum with respect to the Fermi level, and hence reduces the interface recombination rate. Several models have been proposed to explain the properties of this inverted CIGS absorber surface [13]-[25]: the doping model of n-type ODC and the Fermi level pinning model. For our cell, we used the Fermi level pinning model, characterized by a high density, $\left(3 \times 10^{18}\right.$ $\mathrm{cm}^{-3}$ ) of donor defects located at $0.2 \mathrm{eV}$ below the CIGS absorber conduction band. These defects have small capture cross-sections, $\sigma_{n}=\sigma_{p}=10^{-18} \mathrm{~cm}^{2}$, to separate pinning defects from recombination defects of SDL. In our simulations, we considered two deep Gaussian defect distributions with narrow bandwidths: donor defects are assigned to the p-type materials and acceptor defects to then-type materials. The bulk recombination defect states are positioned at mid gap of the respective layers and the interface defects are placed at the mid gap of the lowest band gap of the two adjacent materials, except for buffer-absorber interface donor defects.

The Shockley-Read-Hall model is used within AFORS-HET to describe the recombination currents in bulk levels and the defects at the interface. The current transport across interfaces is describes by drift-diffusion approximation and the front and backside boundaries of the semiconductor stack are described by the flat band metal/semiconductor contact model.

The photon absorption is calculated from the spectral absorption coefficient

$$
\alpha(\lambda)=\frac{4 \pi k(\lambda)}{\lambda}
$$

of each semiconductor layer within the stack and $\alpha(\lambda)$ has been calculated from the extinction coefficient $k(\lambda)$ measured by [26] [27] [28] [29].

\section{Numerical Simulation}

Unlike traditional cells, polycrystalline thin-film solar cells are complicated structures due to the large number of layers and the fact that the properties of the materials involved and mechanisms that govern the operation of these cells are not yet well understood. Less used in the past, numerical modeling is now a current practice and widely approved by scientific community. It allows identi- 
fication of the most important parameters which influence the performance of solar cells and also provides a good understanding their operation since complete devices can now be computationally fabricated, simulated and optimized. Several software packages, among which SCAPS-1D (Solar Cell Capacitance Simulator One dimension), ASA (Amorphous Semiconductor Analysis), PC1-D (Personal Computer One Dimension), AMPS-1D (Analysis of Micro-electronic and Photonic Structures) and AFORS-HET (Automat FOR Simulation for HETerostructures) have been developed to simulate the operation of thin-film solar cells. The advantage of these computer programs is that parameters can be modified on demand, out of the constraints imposed by technological fabrication processes, to simulate relevant mechanisms and provide a clear understanding of the physics of these devices. In this work the powerful numerical simulation tool, AFORS-HET, is used by specifying the parameters listed in Table 1 as inputs. Using Shockley-Read-Hall recombination model, the software numerically solves the one dimensional equations: Poisson's equation and the transport and continuity equations for electrons and holes, governing the semiconductor material under steady-state conditions, and calculates their basic characteristics, such as band diagram, generation and recombination rates, carrier densities and cell currents [30]. The cell is subjected to AM1.5G solar spectrum with an incident power density of $100 \mathrm{~mW} / \mathrm{cm}^{2}$ at room temperature. The Air Mass (AM) quantifies the reduction in the power of light as it passes through the atmosphere and is absorbed by air and dust. The standard spectrum at the Earth's surface is called AM1.5G, (the G stands for global and includes both direct and diffuse radiation). The standard AM1.5G spectrum has been normalized to give $100 \mathrm{~mW} / \mathrm{cm}^{2}$.

We first do not take the effects of reflection on the front and back surfaces, series resistance and shunt resistance into account. For comparison purposes, we first calculate the performances of a n-ZnO:Al/i-ZnO/n-ZnS/p-CIGS/Mo solar cell with our reference parameters corresponding to the same structure with a CdS buffer layer. Figure 2(a) is a plot of the resulting J-V characteristic, with emphasis on the particular values of short circuit current $J_{S O}$ open circuit voltage $V_{O O}$ fill factor FF and conversion efficiency $\eta$, extracted from the J-V curve. Figure 2(b) shows the external quantum efficiency EQE as a function of the wavelength of the incident light.

\section{Results and Discussion}

\subsection{Effect of Ga-Content of Absorber Layer}

As mentioned in the introduction, the band gap of the CIGS depends strongly on the Ga-content of the absorber layer. In turn, the band gap affects various properties of this layer, such as optical absorption coefficient, electron affinity, and bulk defect concentration [31] [32] [33]. Figure 3 shows the solar cell characteristics versus the Ga-content $x$. In the case of $\mathrm{ZnS}$ buffer layer, an optimum efficiency of $26 \%$ is obtained for $x=0.31\left(E_{g}=1.19 \mathrm{eV}\right)$ slightly higher than $25 \%$ obtained with the nominal values of Table 1 . At higher values $x>0.31$, the conversion efficiency drops drastically as a result of AM.1.5G spectral distribution. 


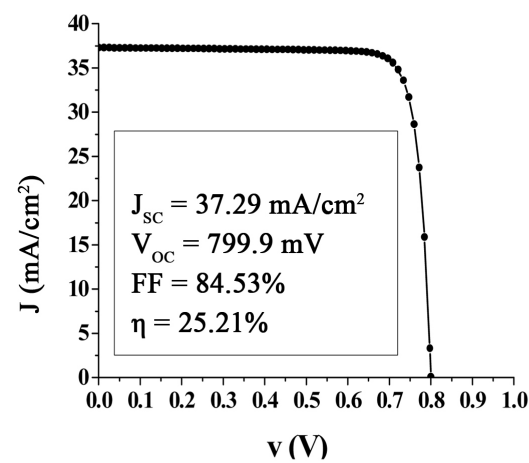

(a)

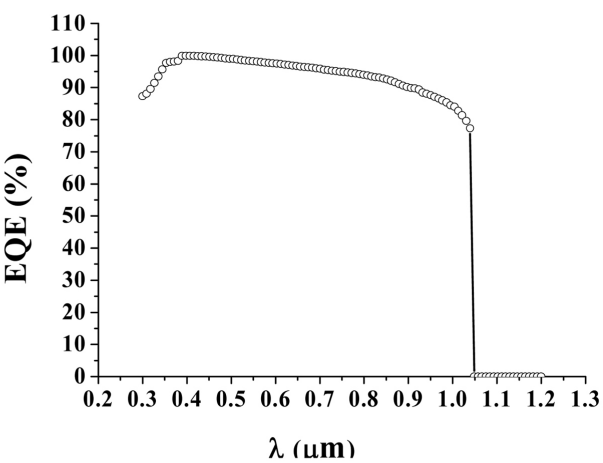

(b)

Figure 2. (a) Current density vs. voltage; and (b) external quantum efficiency of the solar cell.

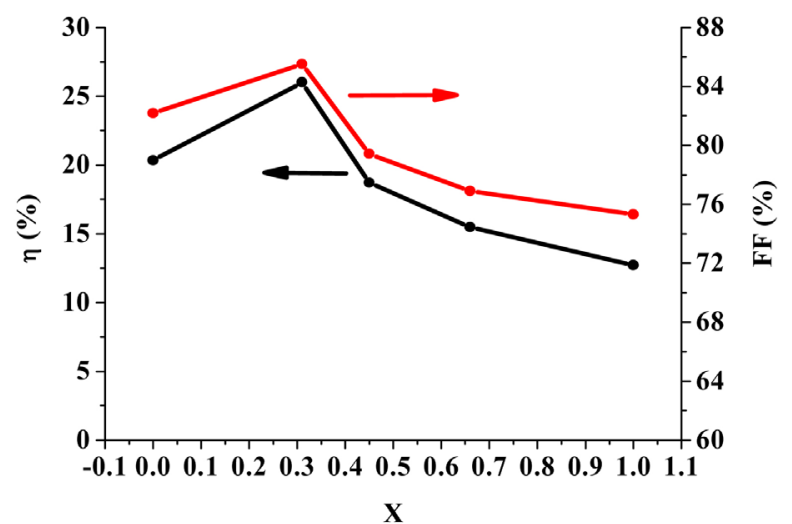

(a)

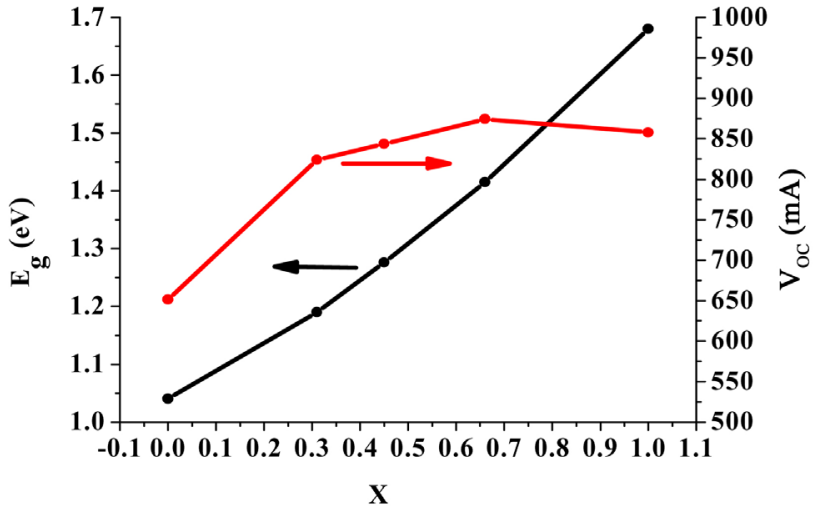

(b)

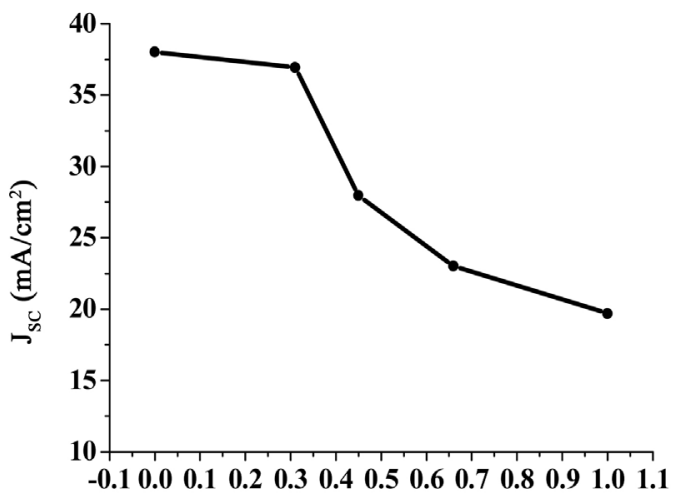

$\mathrm{X}$

(c)

Figure 3. Characteristic parameters of the solar cell as function of the Ga-content: (a) conversion efficiency and fill factor; (b) CIGS band gap and open circuit voltage; (c) short circuit current.

For this reason, we only observe a slight decrease of the conversion efficiency for $x<0.31$. We remind that the maximum theoretical efficiency under AM.1.5G, for an ideally perfect semiconductor, is of $45 \%$ for $E_{g}=1.1 \mathrm{eV}$. Therefore, for $x<$ $0.31, E_{g}$ coming closer to this optical band gap, the loss in conversion efficiency is somehow compensated. The shift of the optimal band gap with respect to its theoretical value can be explained by the bulk defect density in the absorber 
layer which has a minimum value around $10^{15} \mathrm{~cm}^{-3}$, according to G. Hanna et al. [33]. The fill factor follows the same trend as the conversion efficiency, although its variations do not exceed $10 \%$. As expected, $J_{S C}$ decreases and $V_{O C}$ increases with $x$, e.g. the absorber band gap, resulting from a simultaneous reduction of the photo-generation rate and the carrier recombination rate [34]. However, looking into more details, $E_{g}$ and $V_{O C}$ show opposite curvatures (see Figure $3(b))$. To explain this feature, let us remind that the carrier recombination rate depends upon two parameters: 1) the intrinsic carrier concentration, an exponential function of the band gap; and 2) the carrier lifetime. The first term underlines the strong relation between $V_{O C}$ and $E_{g}$. The difference in curvatures is related to the second term and clearly expresses a decrease of the carrier lifetime with increasing band gap. The carrier lifetime decrease is related to the bulk defect concentrations which first decrease from $5 \times 10^{15} \mathrm{~cm}^{-3}$ to $10^{15} \mathrm{~cm}^{-3}$ with increasing Ga-content and increase again to $5 \times 10^{16} \mathrm{~cm}^{-3}$ at $x=1$ [33]. In conclusion, the optimum Ga-content is equal to 0.31 and is very close to values reported in literature [25] [33] [35].

\subsection{Effects of Absorber and Buffer Doping Concentrations}

In this section we successively investigate the effects of the doping levels of the absorber and the defect layers on the CIGS solar cell performances. All electrical properties of the layers are chosen similar to the bulk CIGS, except the energy band gap and the carrier mobilities (see Table 1). Figure 4 represents the variations of the solar cell characteristic parameters versus absorber and buffer doping concentrations. Let us remind that the absorber layer is of p-type and the buffer layer of $n$-type. It has been reported [7] that when the absorber doping is above $10^{17} \mathrm{~cm}^{-3}$ or when the buffer layer doping is below $10^{18} \mathrm{~cm}^{-3}$ the conduction band minimum shift with respect to Fermi level is very high. This means that the Fermi level is no longer pinned and the buffer-absorber interface recombination becomes important. When the buffer layer doping is equal to $10^{18}$ $\mathrm{cm}^{-3}$ and the absorber doping is below $10^{17} \mathrm{~cm}^{-3}$ the Fermi level is pinned. The solar cell performance is then governed by the bulk recombination properties of the absorber layer. This behavior is seen in Figure 4(a) where both the conversion efficiency and FF show an optimum at a doping level of $5 \times 10^{17} \mathrm{~cm}^{-3}$ However, the sensitivity to the absorber doping level is not strong and limited to few percent. Finally, we observe that $\mathrm{J}_{\mathrm{SC}}$ and FF show only slight variation for all absorber doping levels above $10^{17} \mathrm{~cm}^{-3}$. Here, the limiting characteristic is $\mathrm{V}_{\mathrm{OC}}$ which is degraded at low absorber doping levels, reducing the conversion efficiency of the solar cell.

Keeping the absorber layer doping at $5 \times 10^{17} \mathrm{~cm}^{-3}$, Figure $4(\mathrm{~b})$ and Figure 4 (d) shows that the solar cell characteristic parameters change slightly above a buffer layer doping of $10^{18} \mathrm{~cm}^{-3}$, but drop strongly below this doping level because the Fermi level is no longer pinned, except for $V_{o c}$ that is almost constant at all doping levels. 


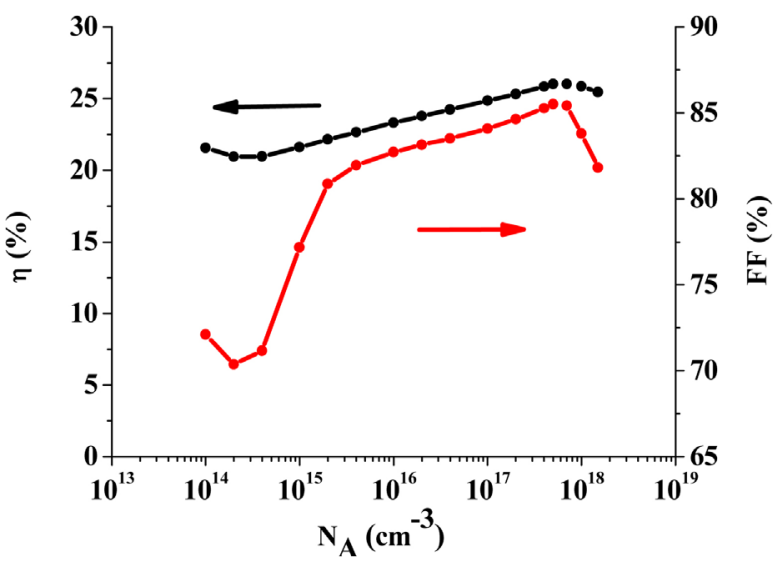

(a)

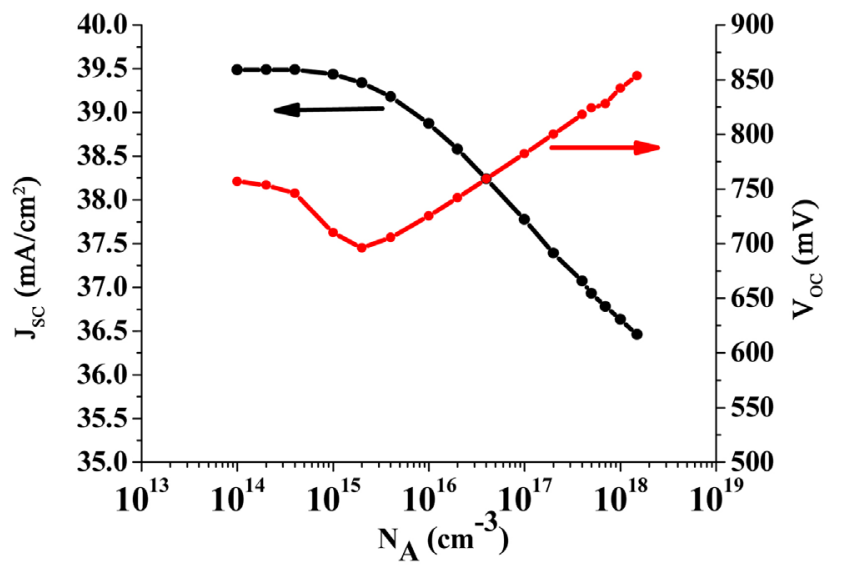

(c)

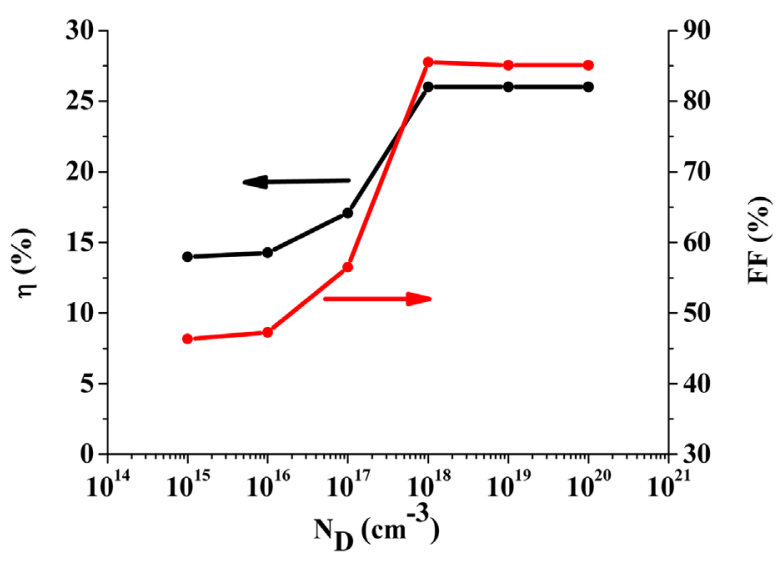

(b)

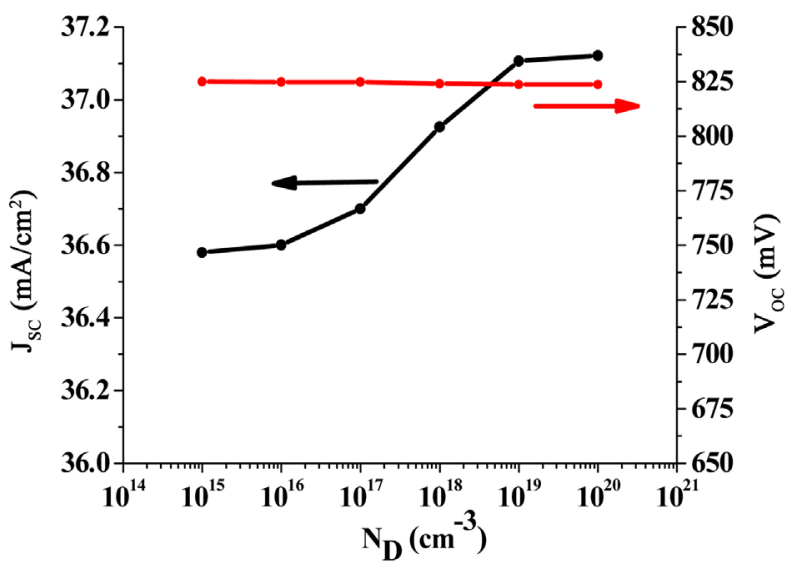

(d)

Figure 4. Characteristic parameters of the solar cell as a function of the carrier concentration in the absorber and buffer layers: (a), (b) conversion efficiency and fill factor; (c), (d) short circuit current and open circuit voltage. $\mathrm{N}_{\mathrm{A}}$ is the acceptor concentration in CIGS layer and $\mathrm{N}_{\mathrm{D}}$ the donor concentration in ZnS layer.

\subsection{Effect of Buffer Layer Thickness}

The role of the buffer layer is to be as much transparent as possible, allowing a maximum sunlight absorption in the absorber layer while maintaining a low interface recombination rate. Here, the main purpose is to reduce the large recombination rate at the upper surface of the solar cells. $\mathrm{ZnS}$ has a wide band gap of $3.6 \mathrm{eV}$, and is therefore transparent to wavelengths below $0.35 \mu \mathrm{m}$ which constitute the major part of the AM.1.5G spectrum. Thus, the optical absorption is essentially confined to CIGS material, minimizing the role of the buffer layer thickness. We have presented these results in Figure 5, the absorber layer thickness being kept at $3 \mu \mathrm{m}$. We see that the optimal buffer thickness is of $30 \mathrm{~nm}$, but all solar cell characteristics show slight sensitivity to this parameter. To illustrate this effect in more detail, we have plotted the external quantum efficiency (EQE) of the solar cell versus the wavelength, for different buffer layer thicknesses $\left(t_{\mathrm{ZnS}}\right)$. Figure 6 shows that the quantum efficiency is almost independent of the $\mathrm{ZnS}$ thickness, except in the narrow range of $\lambda \leq 0.35 \mu \mathrm{m}$. Light absorption 


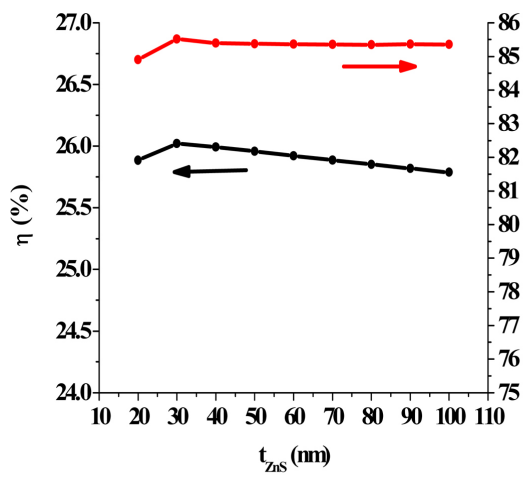

(a)

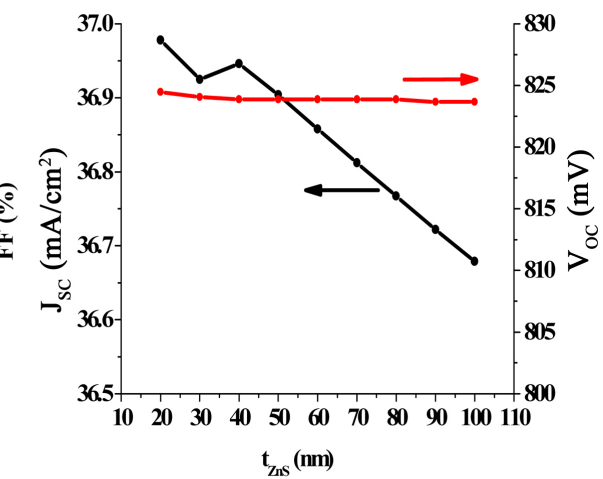

(b)

Figure 5. Characteristic parameters of the solar cell as a function of $\mathrm{ZnS}$ buffer layer thickness: (a) conversion efficiency and fill factor; (b) short circuit current and open circuit voltage.

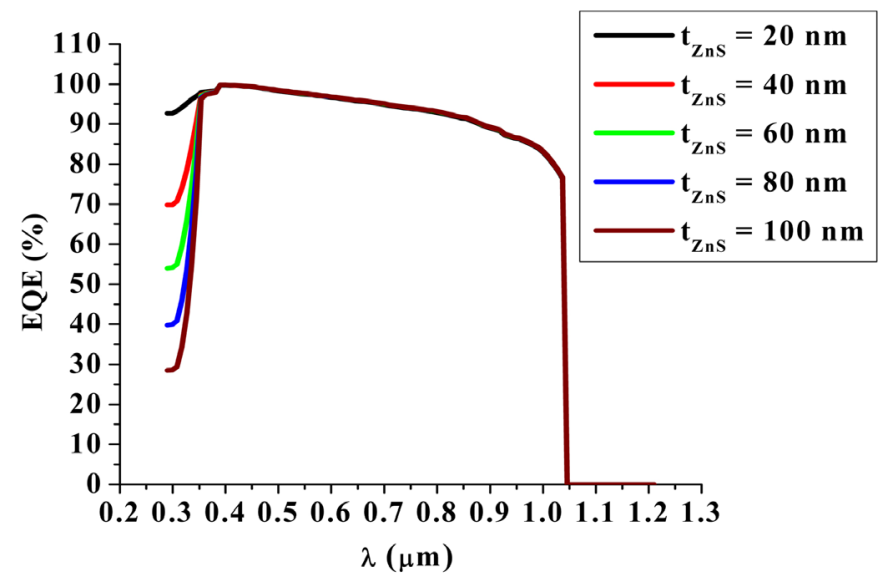

Figure 6. External quantum efficiency of the solar cell for different thicknesses of $\mathrm{ZnS}$ buffer layer.

in this narrow range is at the origin of the $J_{S C}$ decrease for thicknesses over 30 $\mathrm{nm}$, leading to a small loss of efficiency. In conclusion, the buffer layer optimal thickness of $30 \mathrm{~nm}$ should merely be considered as an indication, to be combined with other technological considerations, rather than a mandatory value to be strictly respected.

\subsection{Effect of Absorber Layer Thickness}

Contrary to ZnS, the CIGS layer acts as the absorber, necessitating the use of relatively thick layers. Setting the buffer layer thickness to $30 \mathrm{~nm}$, we represent in Figure 7 the solar cell characteristics as a function of the absorber thickness $\left(t_{\mathrm{CIGS}}\right)$. We observe that the conversion efficiency drop for thicknesses below 1 $\mu \mathrm{m}$, prohibiting the use of very thin layers. For thicknesses above $1 \mu \mathrm{m}$, the conversion efficiency remains relatively flat, with a small slope, reaching $26.3 \%$ at 10 $\mu \mathrm{m}$ thickness. A similar behavior is observed for $J_{S C}$ with higher slope. This result can be interpreted in terms of external quantum efficiency, shown in Figure 8. For thin absorber layers, it can be seen that the sunlight absorption increases 


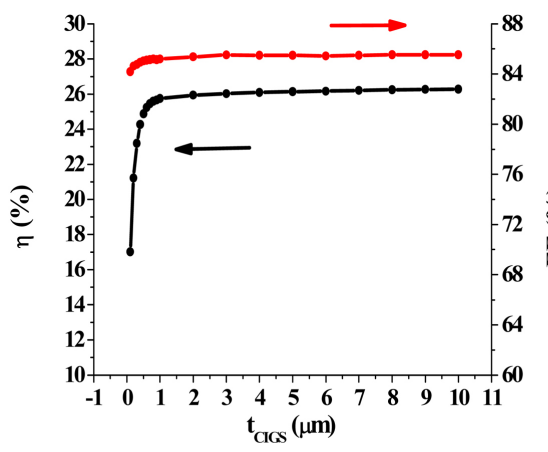

(a)

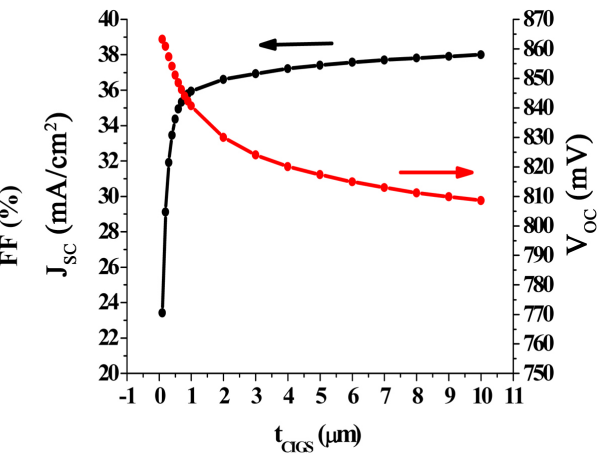

(b)

Figure 7. Characteristic parameters of solar cell as a function of CIGS absorber layer thickness: (a) conversion efficiency and fill factor; (b) short circuit current and open circuit voltage.

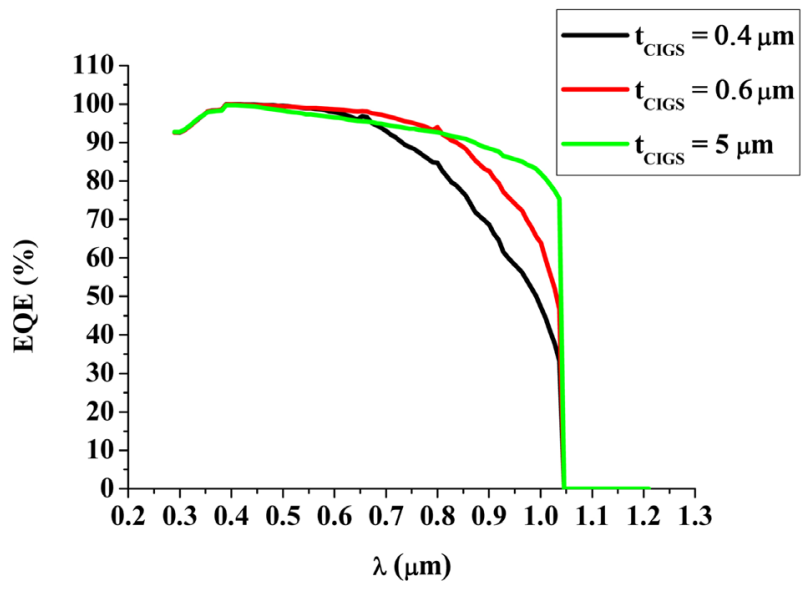

Figure 8. External quantum efficiency of the solar cell for different thicknesses of CIGS absorber layer.

appreciably with the thickness, at wavelengths above $0.6 \mu \mathrm{m}$. However, for thicknesses beyond $5 \mu \mathrm{m}$, the quantum efficiency remains almost unchanged at all wavelengths above the CIGS band gap: we have reached the maximum photon absorption.

Looking now at $V_{O C}$ in Figure 7(b), we observe a decrease of $V_{O C}$ with increasing thickness, due to the increase of the bulk recombination rate. FF is almost constant over the whole range. For thicknesses above $1 \mu \mathrm{m}$, the interesting effect is that the simultaneous increase of $J_{S C}$ and decrease of $V_{O C}$ compensate each other so that the conversion efficiency is hardly affected. As a result, as far as the absorber thickness exceeds $1 \mu \mathrm{m}$, other technological or economic considerations should also be taken into account. Materials cost and availability, concerning indium in particular are of primary importance. The best compromise is a CIGS absorber thickness of $3 \mu \mathrm{m}$ corresponding to a conversion efficiency of $26 \%$.

The optimal values of the solar cell parameters found in this investigation without reflection are reported in Table 2, together with the solar cell perfor- 
mances.

The reflection can easily be taken into account (anti-reflection layer) by modifying the spectral amplitude of the spectrum used on the illuminated front side. The effect of the front side reflection has been investigated on the solar cell performances. Figure 9 represents the variation of the efficiency versus the reflection coefficient. The figure shows that the efficiency decreases almost linearly when the reflection coefficient increases, although its decrease does not exceed $0.35 \%$ when the reflection coefficient reaches $30 \%$. A large reduction of optical losses can be achieved by using a transparent anti-reflet layer which allows better photon transmission to the absorber.

\section{Conclusion}

In this work, the numerical modeling software AFOERS-HET was used to simulate a CIGS-based solar cell operating under AM.1.5G solar spectrum at room

Table 2. Optimum values of the parameters in CIGS solar cells with ZnS buffer layers.

\begin{tabular}{|c|c|c|c|}
\hline \multicolumn{4}{|c|}{ Layers properties } \\
\hline & CIGSe & & $\mathrm{ZnS}$ \\
\hline Thickness $(\mu \mathrm{m})$ & 3 & & 0.03 \\
\hline Band gap $E_{g}(\mathrm{eV})$ & 1.19 & & 3.6 \\
\hline Electron affinity $\chi(\mathrm{eV})$ & 4.5 & & 4.2 \\
\hline Doping level $\left(\mathrm{cm}^{-3}\right)$ & $5 \times 10^{17}(\mathrm{a})$ & & $10^{18}(\mathrm{~d})$ \\
\hline Band offsets & & CIGSe/ZnS & \\
\hline$E_{C}(\mathrm{eV})$ & & 0.3 & \\
\hline$E_{V}(\mathrm{eV})$ & & -2.11 & \\
\hline$\eta(\%)$ & $V_{O C}(\mathrm{mV})$ & $J_{S C}\left(\mathrm{~mA} / \mathrm{cm}^{2}\right)$ & $\mathrm{FF}(\%)$ \\
\hline 26 & 824.1 & 36.9 & 85.5 \\
\hline
\end{tabular}

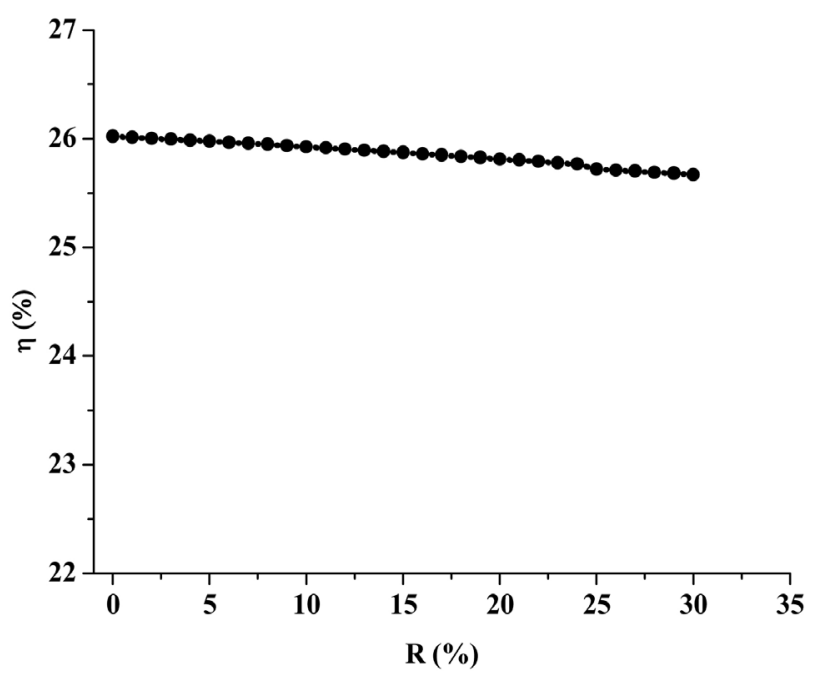

Figure 9. Efficiency of the CIGS/ZnS solar cell versus the reflection coefficient on the front side. 
temperature. We first carried out the calculation of the optimum gallium composition of the CIGS absorber. We find a Ga-content of 0.31 , in good agreement with results reported elsewhere. The simulation of the solar cell gives an optimum efficiency of $26 \%$. The effect of the carrier concentration in CIGS absorber and $\mathrm{ZnS}$ buffer layers on the solar cell characteristic parameters was studied. We find that the optimum carrier concentration in the CIGS absorber layer is of $5 \times$ $10^{17} \mathrm{~cm}^{-3}$ and $10^{18} \mathrm{~cm}^{-3}$ in the ZnS buffer layer which means that the doping must be much greater on the $\mathrm{n}$-doped side than the $\mathrm{p}$-doped side. We also carried out a similar investigation on the influence of the buffer and absorber layers. Simulations give optimum thicknesses of $30 \mathrm{~nm}$ for the buffer layer and 3 $\mu \mathrm{m}$ for the absorber layer. Finally, calculating the quantum efficiency, we show how an increase of the buffer layer thickness degrades the solar cell performances while an increase of the absorber layer thickness improves the solar cell efficiency.

\section{References}

[1] Wei, S.-H., Zhang, S.B. and Zunger, A. (1998) Effects of Ga Addition to CuInSe $e_{2}$ on Its Electronic, Structural, and Defect Properties. Applied Physics Letters, 72, 3199. https://doi.org/10.1063/1.121548

[2] Huang, C.H. (2008) Effects of Ga Content on $\mathrm{Cu}(\mathrm{In}, \mathrm{Ga}) \mathrm{Se}_{2}$ Solar Cells Studied by Numerical Modelling. Journal of Physics and Chemistry of Solids, 69, 330-334. https://doi.org/10.1016/j.jpcs.2007.07.093

[3] Green, M.A., Hishikawa, Y., Warta, W., Dunlop, E., Levi, D., Hohl-Ebinger, J. and Ho-Baillie, A.W.H. (2017) Solar Cell Efficiency Tables (Version 50). Progress in Photovoltaics, 25, 668-676. https://doi.org/10.1002/pip.2909

[4] Pianezzi, F., Reinhard, P., Chiril, A., Nishiwaki, S., Bissig, B., Buecheler, S. and Tiwari, A.N. (2013) Defect Formation in $\mathrm{Cu}(\mathrm{In}, \mathrm{Ga}) \mathrm{Se}_{2}$ Thin Films Due to the Presence of Potassium during Growth by Low Temperature Co-Evaporation Process. Journal of Applied Physics, 114, Article ID: 194508. https://doi.org/10.1063/1.4832781

[5] Pohl, J. and Albe, K. (2013) Intrinsic Point Defects in CuInSe $e_{2}$ and $\mathrm{CuGaSe}_{2}$ as Seen via Screened-Exchange Hybrid Density Functional Theory. Physical Review B, 87, Article ID: 245203. https://doi.org/10.1103/PhysRevB.87.245203

[6] Ahn, B.T., Larina, L., Kim, K.H. and Ahn, S.J. (2008) Development of New Buffer Layers for $\mathrm{Cu}(\mathrm{In}, \mathrm{Ga}) \mathrm{Se}_{2}$ Solar Cells. Pure and Applied Chemistry, 80, 2091-2102. https://doi.org/10.1351/pac200880102091

[7] Pettersson. J. (2012) Modeling Band Gap Gradients and Cd-Free Buffer Layers in $\mathrm{Cu}(\mathrm{In}, \mathrm{Ga}) \mathrm{Se}_{2}$ Soalr Cells. Ph.D. Thesis, Uppsala University, Uppsala.

[8] Meyer, B.K., Polity, A., Farangis, B., He, Y., Hasselkamp, D., Krämer, Th. and Wang, C. (2004) Structural Properties and Band Gap Bowing of $\mathrm{ZnO}_{1-\mathrm{x}} \mathrm{S}_{\mathrm{x}}$ Thin Films Deposited by Reactive Sputtering. Applied Physics Letters, 85, 4929-4931. https://doi.org/10.1063/1.1825053

[9] Gloeckler, M., Fahrenbruch, A.L. and Sites, J.R. (2003) Numerical Modeling of CIGS and CdTe Solar Cells: Setting the Baseline. $3^{\text {rd }}$ World Conference of Photovoltaic Energy Conversion, Osaka, 11-18 May 2003.

[10] Abou-Ras, D., Kostorz, G., Bremaud, D., Kalin, M., Kurdesau, F.V., Tiwari, A.N. and Dobeli, M. (2005) Formation and Characterization of $\mathrm{MoSe}_{2}$ for $\mathrm{Cu}(\mathrm{In}, \mathrm{Ga}) \mathrm{Se}_{2}$ 
Based Solar Cells. Thin Solid Films, 480-481, 433-438. https://doi.org/10.1016/j.tsf.2004.11.098

[11] Kohara, N., Nishiwaki, S., Hashimoto, Y., Negami, T. and Wada, T. (2001) Electrical Properties of the $\mathrm{Cu}(\mathrm{In}, \mathrm{Ga}) \mathrm{Se}_{2} / \mathrm{MoSe}_{2} / \mathrm{Mo}$ Structure. Solar Energy Materials \& Solar Cells, 67, 209-215.

[12] Wurz, R., Fuertes Marron, D., Meeder, A., Rumberg, A., Babu, S.M., Schedel Niedrig, T., Bloeck, U., Schubert-Bischoff, P. and Lux-Steiner, M.C. (2003) Formation of an Interfacial $\mathrm{MoSe}_{2}$ Layer in CVD Grown CuGaSe ${ }_{2}$ Based Thin Film Solar Cells. Thin Solid Films, 431-432, 398-402.

[13] Yan, Y., Jones, K. M., Abushama, J., Young, M., Asher, S., Al-Jassim, M.M. and Noufi, R. (2002) Microstructure of Surface Layers in $\mathrm{Cu}(\mathrm{In}, \mathrm{Ga}) \mathrm{Se}_{2}$ Thin Films. $A p$ plied Physics Letters, 81, 1008. https://doi.org/10.1063/1.1498499

[14] Herberholz, R., Rau, U., Schock, H.W., Haalboom, T., Gödecke, T., Ernst, F., Beilharz, C., Benz, K.W. and Cahen, D. (1999) Phase Segregation, Cu Migration and Junction Formation in $\mathrm{Cu}(\mathrm{In}, \mathrm{Ga}) \mathrm{Se}_{2}$. The European Physical Journal Applied Physics, 6, 131. https://doi.org/10.1051/epjap:1999162

[15] Zhang, S.B., Wei, S.-H., Zunger, A. and Yoshida, H.K. (1998) Defect Physics of the $\mathrm{CuInSe}_{2}$ Chalcopyrite Semiconductor. Physical Review B, 57, 9642. https://doi.org/10.1103/PhysRevB.57.9642

[16] Schmid, D., Ruckh, M., Grunwald, F. and Schock, H.W. (1993) Chalcopyrite/Defect Chalcopyrite Heterojunctions on the Basis of CuInSe ${ }_{2}$. Journal of Applied Physics, 73, 2902.

[17] Schmid, D., Ruckh, M. and Werner Schock, H. (1996) A Comprehensive Characterization of the Interfaces in Mo/CIS/CdS/ZnO Solar Cell Structures. Solar Energy Material and Solar Cells, 41-42, 281-294.

[18] Li, Z., Nishijima, M., Yamada, A. and Konagai, M. (2009) Growth of Cu(In,Ga)Se Thin Films using Ionization Ga Source and Application for Solar Cells. Physica Status Solidi, 6, 1273-1277. https://doi.org/10.1002/pssc.200881180

[19] Zunger, A., Zhang, S.B. and Wei, S.-H. (1998) Revisiting the Defect Physics in Cu$\mathrm{InSe}_{2}$ and $\mathrm{CuGaSe}_{2}$. In: Basore, P.A. (Ed.), Proceedings of the 26 th IEEE PV Specialist Conference, AIP, New York, 313.

[20] Levcenko, S., Durán, L., Gurieva, G., Alonso, M.I., Arushanov, E., Durante Rincón, C.A. and León, M. (2010) Optical Constants of $\mathrm{Cu}\left(\mathrm{In}_{1-\mathrm{x}} \mathrm{Ga}_{\mathrm{x}}\right)_{5} \mathrm{Se}_{8}$ Crystals. Journal of Applied Physics, 107, Article ID: 033502. https://doi.org/10.1063/1.3298499

[21] Zhao, H., Kumar, M. and Persson, C. (2012) Density Functional Theory Study of Ordered Defect Cu-(In,Ga)-Se Compounds. Physica Status Solidi, 9, 1600-1603. https://doi.org/10.1002/pssc.201100671

[22] Kwon, S.H., Park, S.C., Ahn, B.T., Yoon, K.H. and Song, J. (1998) Effect of $\mathrm{CuIn}_{3} \mathrm{Se}_{5}$ Layer Thickness on CuInSe 2 Thin Films and Devices. Solar Energy, 64, 55-60.

[23] Dharmadasa, I.M. (2009) Fermi Level Pinning and Effects on CuInGaSe $\mathrm{C}_{2}$-Based Thin-Film Solar Cells. Semiconductor Science and Technology, 24, Article ID: 055016.

[24] Jaffe, J.E. and Zunger, A. (1984) Theory of the Band-Gap Anomaly in $\mathrm{ABC}_{2}$ Chalcopyrite Semiconductors. Physical Review B, 29, 1882-1906.

[25] Huang, C.-H. (2008) Effects of Junction Parameters on $\mathrm{Cu}(\mathrm{In}, \mathrm{Ga}) \mathrm{Se}_{2}$ Solar Cells. Journal of Physics and Chemistry of Solids, 69, 779-783.

[26] Richter, M., Schubbert, C., Eraerds, P., Riedel, I., Keller, J., Parisi, J., Dalibor, T. and Avellán-Hampe, A. (2013) Optical Characterization and Modeling of $\mathrm{Cu}(\mathrm{In}, \mathrm{Ga})(\mathrm{Se}, \mathrm{S})_{2}$ 
Solar Cells with Spectroscopic Ellipsometry and Coherent Numerical Simulation. Thin Solid Films, 535, 331-335.

[27] Paulson, P.D., Birkmire, R.W. and Shafarman, W.N. (2003) Optical Characterization of $\mathrm{CuIn}_{1-\mathrm{x}} \mathrm{Ga}_{\mathrm{x}} \mathrm{Se}_{2}$ Alloy Thin Films by Spectroscopic Ellipsometry. Journal of Applied Physics, 94, 879. https://doi.org/10.1063/1.1581345

[28] G. Yin Chao de Hubei, Chine (2015) Preparation of Ultra-Thin CuIn ${ }_{1-x} \mathrm{Ga}_{\mathrm{x}} \mathrm{Se}_{2}$ Solar Cells and Their Light Absorption Enhancement. Présenté à la Faculté III-Sciences des processus de l'Université technique de Berlin pour l'obtention du diplôme universitaire de Docteur en génie.

[29] Alonso, M.I., Garriga, M., Durante Rincon, C.A., Hernandez, E. and Leon, M. (2002) Optical Functions of Chalcopyrite $\mathrm{CuGa}_{\mathrm{x}} \mathrm{In}_{1-\mathrm{x}} \mathrm{Se}_{2}$ Alloys. Applied Physics $A$, 74, 659-664. https://doi.org/10.1007/s003390100931

[30] Simulation of Heterojunction Solar Cells with AFORS-HET. http://shodhganga.inflibnet.ac.in/bitstream/10603/42510/8/09_chapter\%204.pdf

[31] Huang, C.-H. (2008) Effects of Ga Content on $\mathrm{Cu}(\mathrm{In}, \mathrm{Ga}) \mathrm{Se}_{2}$ Solar Cells Studied by Numerical Modeling. Journal of Physics and Chemistry of Solids, 69, 330-334.

[32] Wei, S.-H. and Zunger, A. (1995) Band Offsets and Optical Bowings of Chalcopyrites and Zn-Based II-VI Alloys. Journal of Applied Physics, 78, 3846-3856. https://doi.org/10.1063/1.359901

[33] Hanna, G., Jasenek, A., Rau, U. and Schock, H.W. (2001) Influence of Ga-Content on the Bulk Defect Densities of $\mathrm{Cu}(\mathrm{In}, \mathrm{Ga}) \mathrm{Se}_{2}$. Thin Solid Films, 387, 71-73.

[34] Touafek, N. and Mahamdi, R. (2014) Back Surface Recombination Effect on the Ultra-Thin CIGS Solar Cells by SCAPS. International Journal of Renewable Energy Research, 4, 958-964.

[35] Amin, N., Chelvanathan, P., Hossain, M.I. and Sopian, K. (2012) Numerical Modelling of Ultra ThinCu(In,Ga)Se 2 Solar Cells. Energy Procedia, 15, 291-298. 